\title{
Remuneration Of Employee Performance (Work Satisfaction and Motivation as a Variable of Mediation)
}

\author{
Hayatul Islam ${ }^{1}$, Femei Purnamasari ${ }^{2}$ \\ \{hayatulislam@radenintan.ac.id ${ }^{1}$, femeipurnamasari@ radenintan.ac.id ${ }^{2}$ \} \\ ${ }^{1,2}$ UIN Raden Intan Lampung, Jl. Letnal Kolonel Endro Suratmin, Sukarame, Bandar Lampung, \\ Indonesia
}

\begin{abstract}
This study aims to find empirical evidence of the effect of remuneration on employee performance in the public sector at the Raden Intan Lampung State Islamic University with job satisfaction and motivation as mediating variables. This study uses the SEM-PLS data analysis method with a sample of 53 lecturer respondents and 47 tendant respondents using the purposive judgment sampling method.The results showed that remuneration had a positive influence on motivation and job satisfaction of both lecturers and students. The same thing also happens to the relationship between lecturer and tendency motivation towards performance, while the relationship between job satisfaction and performance has different results with lecturer and academic staff, tendency of job satisfaction does not have a positive effect on performance. Interesting results also occur in the relationship between remuneration on performance.This study shows that remuneration does not affect the performance, both lecturer and student performance. Meanwhile mediation relations has the results that show motivation and job satisfaction of lecturers can mediate the relationship between remuneration and lecturer performance, and for academic staff, it is found that motivation mediates the relationship between remuneration and tendency performance, but job satisfaction does not mediate.[1]
\end{abstract}

Keywords: Employee Performance, Job Satisfaction, Motivation, Remuneration.

\section{Introduction}

This modern government system is believed to provide the right direction to encourage the public sector to be more outcomes oriented, more proactive and agile, which in turn will increase effectiveness towards better public services. One of the most phenomenal and key things in this system is the implementation of incentive policies to improve efficiency in the public sector. This scheme is a practice adopted by the business sector and adopted by modern governments in various countries, known as pay for performance or performance-related pay schemes, in Indonesia known as performance benefits or remuneration.

In Indonesia, one of the country's financial reform agendas is a shift from traditional budgeting to performance-based budgeting. With this performance basis, the direction of using government funds is expected to be clearer, than just funding inputs and the process of becoming output-oriented, and more effective and efficient, more effective and targeted, which in turn will improve services to the community. These provisions have been stated in Law No. 17 of 2003 concerning State Finance.[2] 
Financial reform is an inseparable part of bureaucratic reform, through Menpan Regulation No.15 / 2008 which was later strengthened by Presidential Regulation No. 81/2010, the government has issued guidelines on the Grand Design of the 2010-2025 Bureaucracy Reform, which is a blueprint for bureaucratic reform until year 2025. Bureaucratic reform means a major change in the paradigm and governance of Indonesia, with the aim of creating a professional government bureaucracy with adaptive characteristics, integrity, high performance, clean and free of $\mathrm{KKN}$, able to serve the public, neutral, prosperous, dedicated and upholding the basic values and code of ethics of the state apparatus. Thus bureaucratic reform is expected to be able to create a government that is clean and free of corruption, collusion and nepotism, improve public services to the community and be able to increase the capacity and accountability of bureaucratic performance.

The regulation is also explicitly stated that the implementation of bureaucratic reform is expected to be able to encourage improvement and increase the performance of government bureaucracy. Performance will improve if there is strong motivation overall, both at the center and in the regions.[3] Motivation will arise if each program / activity carried out produces outputs, value added, outcomes and benefits that are better from year to year, accompanied by a reward and punishment system implemented consistent and sustainable. With this regulatory basis, the government began implementing a performance-based pay or performance system, known as performance benefits or remuneration, in our governance as an inseparable part of bureaucratic reform.

State Islamic University Raden Intan Lampung (UIN), which is one of the government agencies under the Ministry of Religion of the Republic of Indonesia provides public services in the field of education, mandatory to implement this policy. As a work unit that has been designated as a Public Service Agency (BLU) since 2010 (through the Decree of the Minister of Finance Number: 277 / KMK.05 / 2010),[4] UIN Raden Intan Lampung has an obligation to provide remuneration to all of its employees. This provision is contained in Minister of Finance Regulation Number 10 of 2006 as amended to Minister of Finance Regulation Number 73 of 2007 concerning Guidelines for Determining Remuneration for Officers, Managers, Supervisory Board, and Employees of Public Service Agencies.

Through the Minister of Finance Decree No. 133 / KMK.05 / 2017 concerning the Determination of Remuneration for Managing Officers, Supervisory Board and Employees of the Public Service Agency of UIN Raden Intan Lampung, since January 2017 employees of UIN Raden Intan Lampung received incentives in the form of financial benefits known as' remuneration '. Remuneration referred to in the Decree of the Minister of Finance (KMK) [5] is a work benefit that can be in the form of salary, honorarium, fixed allowances, incentives, bonuses for achievement, severance pay, and / or pensions, the amount of which is adjusted to the ability of the BLU's income and is determined by the Minister of Finance. based on the proposals from each BLU.

The remuneration given to BLU management officials / employees is sourced from PNBP based on the achievements of the Key Performance Index or Key Performance Indicators (IKU) for the year specified in the performance contract. With that hope, this remuneration can improve the performance of UIN Raden Intan Lampung employees.

The implementation of the remuneration system or performance-based pay or pay for performance in government organizations (public sector) has attracted the interest of researchers. Various studies about this system have been conducted, and there is an interesting debate about the effect of remuneration in improving the performance of government employees. 
If in the private sector it has been empirically proven that remuneration has significantly affected productivity, such as research conducted by Lazear (2000) which shows that the application of incentives has increased the productivity of Safelite Auto Glass factory glass workers by $20 \%$. Likewise, research conducted by Oluigbo and Anyiam (2014) found that compensation helped increase the output / productivity of workers in Information Technology companies and suggested that management take all measures to provide incentives to improve the work ethic of its employees. And the results of the study of Hameed et al. (2014) who found that compensation had a positive and significant influence on the performance of Bank employees in Pakistan. What about its application in the public sector? Will it produce the same effect as what happens in the private sector? Several studies conducted found mixed results. There are two main opinions regarding the issue of performance-related benefits, on the one hand researchers with a background in traditional economic theory and management behavior theory argue that performance-related benefits (remuneration) will improve individual performance if properly designed.[6] Therefore these researchers focus their research on the techniques to implement this remuneration scheme. As a study conducted by Burgess (2003) who examined how optimal incentives for employees in the public sector compared to employees in the UK private sector, found that the implementation of performance-based incentive schemes (remuneration) in the public sector was more problematic than in the private sector because of the multi- tasking, multi-principal, difficulty in determining output size (performance) and the issue of intrinsic motivation from individual employees in the public sector. Therefore Burgess concluded that the remuneration scheme in the public sector would be optimal depending on the type of organization.

Weibelet al. (2010) tried to analyze whether the effect of remuneration on performance is bound to certain conditions? and if true, under what conditions remuneration has positive and negative effects on performance. This study found that remuneration increases performance in unattractive task conditions, whereas remuneration actually decreases performance in attractive task conditions. This study also shows that motivation is a key influence on the remuneration relationship on performance. Several studies have found that remuneration[7] has a positive effect on employee performance. As in the research of Kahn et al. (2001) who examined the effect of applying remuneration to the Brazilian tax office and found that applying remuneration affected the level of tax payments, Lavy (2007) found that remuneration had improved teacher performance in the United States and Israel. Likewise with the research of Palagia et al. (2012), and who also found that remuneration affected the performance of tax office employees in Makassar.[8]

While on the other hand, researchers with a background in economic psychology argue that the fundamental problem with the implementation of remuneration schemes related to performance in the public sector is that this scheme can damage individual performance when faced with job satisfaction. Where job satisfaction is also influenced by other variables besides remuneration, they therefore include job satisfaction as an important moderator of the effect of remuneration on performance.

From the debates and phenomena that arise in the issue of the application of performance-related benefits (remuneration) and their effects on performance in the public sector as mentioned above, the author is interested in conducting a study entitled "The Effect of Remuneration on the Performance of Raden Intan Lampung State Islamic University Employees With Job Satisfaction And Motivation as A Moderating Variable".

Based on the background stated above, the following questions in this study are as follows:

1. Remuneration for motivation? 
2. Remuneration for job satisfaction?

3. Motivation for performance?

4. Job satisfaction on performance?

5. Remuneration for performance?

6. Job satisfaction mediates the relationship between remuneration and performance?

7. Motivation mediates the relationship between remuneration and performance?

[9]

\section{Methodology}

Based on the characteristics of the problem under study, this research is a descriptive study which is a study that describes a certain condition by looking at observed phenomena and symptoms regarding the implementation of remuneration in the public sector in this case UIN Raden Intan Lampung, with the aim to test hypotheses or answer related questions with the current status of the effect of the implementation of the remuneration on performance and see the mediating effect of motivation and job satisfaction on the relationship of remuneration and performance.

The approach used is a quantitative approach

Table 1. The Amount of Population

\begin{tabular}{|c|l|c|}
\hline NO & \multicolumn{1}{|c|}{ CATEGORY } & $\begin{array}{c}\text { NUMBER } \\
\text { (PEOPLE) }\end{array}$ \\
\hline 1 & Lecturer with additional task (DTT) & 116 \\
\hline 2 & Lecturer (DB) & 163 \\
\hline 3 & Academic Staff Eselon (TE) & 37 \\
\hline 4 & Academic Staff with functional position (TJF) & 14 \\
\hline 5 & Academic Staff (TB) & 121 \\
\hline & Amount & 451 \\
\hline
\end{tabular}

Source : Personnel Division of UIN RadenIntan Lampung (2018)

The calculation of the number of samples taken as many as 125 people using proportional stratified random sampling based on class position and employee categories with the following details.[10] 
Table 2. Population and Calculation of Proportion Sample

\begin{tabular}{|c|c|c|c|c|c|c|c|c|c|c|c|c|c|}
\hline \multirow{2}{*}{ NO } & \multirow{2}{*}{$\begin{array}{c}\text { DESIGNA } \\
\text { TION } \\
\text { CLASS }\end{array}$} & \multicolumn{6}{|c|}{ POPULATION (PEOPLE) } & \multicolumn{6}{|c|}{ SAMPLE (PEOPLE) } \\
\hline & & DTT & DB & $\mathbf{T E}$ & TJF & TB & $\begin{array}{l}\text { NUM } \\
\text { BER }\end{array}$ & DTT & DB & TE & TJF & TB & $\begin{array}{l}\text { NUM } \\
\text { BER } \\
\end{array}$ \\
\hline 1 & 17 & 1 & & & & & 1 & & & & & & \\
\hline 2 & 16 & 4 & & & & & 4 & 1 & & & & & 1 \\
\hline 3 & 15 & 5 & & & & & 5 & 1 & & & & & $\mathbf{1}$ \\
\hline 4 & 14 & & & 2 & & & 2 & & & 1 & & & 1 \\
\hline 5 & 13 & 3 & & & & & 3 & 1 & & & & & 1 \\
\hline 6 & 12 & 16 & & & & & 16 & 4 & & & & & 4 \\
\hline 7 & 11 & & 10 & 10 & 4 & & 24 & & 3 & 3 & 1 & & 7 \\
\hline 8 & 10 & 14 & & & & & 14 & 4 & & & & & 4 \\
\hline 9 & 9 & 36 & & 25 & 6 & & 67 & 10 & & 7 & 2 & & 19 \\
\hline 10 & 8 & 37 & & & 2 & & 39 & 10 & & & 1 & & 11 \\
\hline 11 & 7 & & & & 2 & 16 & 18 & & & & 1 & 4 & 5 \\
\hline 12 & 6 & & & & & 94 & 94 & & & & & 26 & 26 \\
\hline 13 & 5 & & 69 & & & 11 & 80 & & 19 & & & 3 & 22 \\
\hline 14 & 4 & & 51 & & & & 51 & & 14 & & & & 14 \\
\hline 15 & 3 & & 33 & & & & 33 & & 9 & & & & 9 \\
\hline & JUMLAH & 116 & 163 & 37 & 14 & 121 & 451 & 31 & 45 & 11 & 5 & 33 & 125 \\
\hline
\end{tabular}

In this study data were analyzed using Structural Equation Model (SEM) with Partial Least Square (PLS) approach. Analysis on PLS is carried out in 3 (three) stages, namely; outer model analysis (measurement model analysis), inner model analysis (structural model analysis) and hypothesis testing.

\section{Results}

The simple framework for this research model can be seen in the diagram of the research framework as follows:

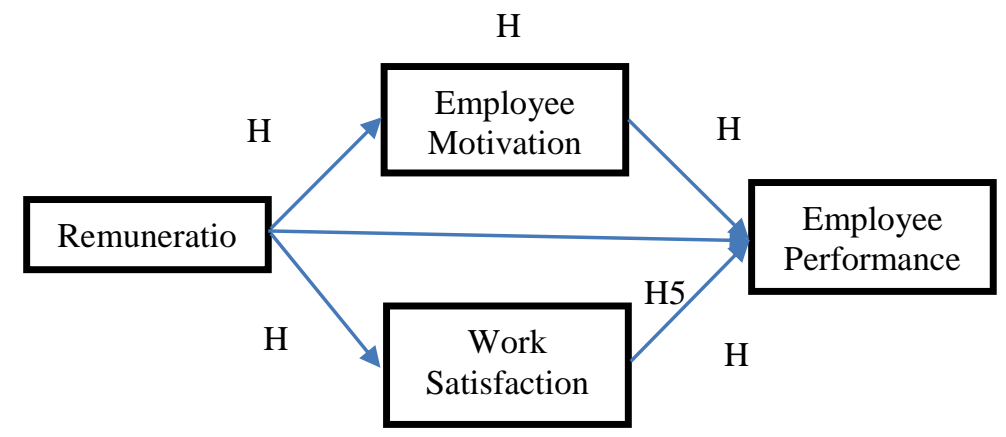

$\mathrm{H}$

Fig. 1. Theoretical Framework

This study uses a questionnaire instrument to measure indicators, there are 4 (four) research variables, namely employee performance variables hereinafter referred to (Y) as endogenous variables (dependant), and remuneration variables hereinafter referred to (X1), 
motivational variables subsequently called ( X2) and the job satisfaction variable hereinafter referred to as (X3) as an electronic (independent) variable.

Table 3. Employee Performance Operational Variable

\begin{tabular}{|l|l|l|}
\hline Dimension & \multicolumn{1}{|c|}{ Indicator } & \multicolumn{1}{c|}{ Statement } \\
\hline \multirow{2}{*}{ Quality } & \multirow{2}{*}{ Quality Target } & I finish my job based on SOP given(KIN1) \\
\cline { 3 - 3 } & & I am capable of doing my job description (KIN2) \\
\hline Quantity & Quantity Target & I don't try to reach target given $®(\mathrm{KIN} 3)$ \\
\hline Time & Time Target & I don't try to finish job punctually (KIN4) \\
\hline
\end{tabular}

Source : PP 46/2011 with adjustment

Exogenous or independent variables are variables that affect the dependent variable both positively and negatively. Exogenous variables in this study are: remuneration (X1), motivation (X2) and job satisfaction (X3).

Table 4. Remuneration Operational Variables

\begin{tabular}{|c|c|c|}
\hline Dimension & Indicator & Statement \\
\hline \multirow{4}{*}{$\begin{array}{l}\text { Transparency, } \\
\text { according to } \\
\text { Thierry (1987) } \\
\text { in Susi (2017) }\end{array}$} & \multirow{2}{*}{$\begin{array}{l}\text { Remuneration } \\
\text { Number } \\
\text { Infirmation }\end{array}$} & $\begin{array}{l}\text { I understand the more performance I have, the } \\
\text { higher remuneration I got(REM1) }\end{array}$ \\
\hline & & $\begin{array}{l}\text { I can plan the remuneration target that I can get } \\
\text { in this semester( } R E M 2)\end{array}$ \\
\hline & \multirow{2}{*}{$\begin{array}{l}\text { Criteria/Require } \\
\text { ment must be } \\
\text { fullfilled }\end{array}$} & $\begin{array}{l}\text { I understand how to reach remun point that I } \\
\text { plan in this semester(REM3) }\end{array}$ \\
\hline & & $\begin{array}{l}\text { I know how to count remuneration } \\
\text { point(REM4) }\end{array}$ \\
\hline \multirow[b]{3}{*}{$\begin{array}{l}\text { Justice, } \\
\text { according to } \\
\text { Thierry (1987) } \\
\text { in Susi }(2017)\end{array}$} & \multirow[b]{3}{*}{ ormance Measurer } & $\begin{array}{l}\text { The new remuneration system is able to } \\
\text { distinguish between high-performance } \\
\text { employees and those with low performance }\end{array}$ \\
\hline & & $\begin{array}{l}\text { I feel my workload and performance are being } \\
\text { rewarded with this new remuneration(REMG) }\end{array}$ \\
\hline & & $\begin{array}{l}\text { My income from remuneration is in accordance } \\
\text { with the performance and burden of the work } \\
\text { that I do (REM7) }\end{array}$ \\
\hline
\end{tabular}

Source: Susi (2017) with adjustments

Employee motivation variables will be measured by 2 (two) dimensions, namely intrinsic motivation and extrinsic motivation, as developed in the previous study of Calder \& Staw (1975) in Susi (2017).[11] According to Frey (1997) in Susi (2017) what is meant by extrinsic motivation is motivation that is obtained externally which can affect satisfaction, and therefore stimulated with rewards or financial incentives. There is intrinsic motivation is motivation that comes from within the individual, for example motivation to perform better, not too concerned about the impact. 
Table 5. Employee Motivation Variable Operational

\begin{tabular}{|c|c|c|}
\hline Dimension & Indicator & Statement \\
\hline \multirow{3}{*}{$\begin{array}{l}\text { Extrinsicn } \\
\text { Motivation, } \\
\text { according to } \\
\text { Calder \& Staw } \\
(1975) \text { in Susi } \\
(2017)\end{array}$} & \multirow{3}{*}{ Award } & $\begin{array}{l}\text { The remuneration system keeps me motivated to } \\
\text { work optimally (MOT1) }\end{array}$ \\
\hline & & $\begin{array}{l}\text { I am excited to achieve maximum remuneration } \\
\text { points (MOT2) }\end{array}$ \\
\hline & & $\begin{array}{l}\text { I feel that the remuneration system is motivating } \\
\text { enough(MOT3) }\end{array}$ \\
\hline \multirow{4}{*}{$\begin{array}{l}\text { Intrinsic } \\
\text { Motivation, } \\
\text { according to } \\
\text { Calder \& Staw } \\
(1975) \text { in Susi } \\
(2017)\end{array}$} & \multirow{2}{*}{ Pride } & I am satisfied with the work that I do (MOT4) \\
\hline & & My work is worth the effort I do (MOT5) \\
\hline & \multirow{2}{*}{ Challenge } & $\begin{array}{l}\text { I often feel compelled to do work assignments }{ }^{\circledR} \\
\text { (MOT6) }\end{array}$ \\
\hline & & I usually feel excited to work (MOT7) \\
\hline
\end{tabular}

Source : Susi (2017) with adjustment

Table 6. Work Satisfaction Variable Operational

\begin{tabular}{|c|c|c|}
\hline Dimension & Indicator & Statement \\
\hline \multirow{4}{*}{$\begin{array}{l}\text { Transparency, } \\
\text { according to } \\
\text { Thierry (1987) } \\
\text { in Susi (2017) }\end{array}$} & \multirow{2}{*}{$\begin{array}{l}\text { Remuneration } \\
\text { Number } \\
\text { Infirmation }\end{array}$} & $\begin{array}{l}\text { I understand the more performance I have, the } \\
\text { higher remuneration I got(REM1) }\end{array}$ \\
\hline & & $\begin{array}{l}\text { I can plan the remuneration target that I can get in } \\
\text { this semester(REM2) }\end{array}$ \\
\hline & \multirow{2}{*}{$\begin{array}{l}\text { Criteria/Requirem } \\
\text { ent must be } \\
\text { fullfilled }\end{array}$} & $\begin{array}{l}\text { I understand how to reach remun point that I plan } \\
\text { in this semester(REM3) }\end{array}$ \\
\hline & & I know how to count remuneration point(REM4) \\
\hline \multirow[b]{3}{*}{$\begin{array}{l}\text { Justice, } \\
\text { according to } \\
\text { Thierry (1987) in } \\
\text { Susi (2017) }\end{array}$} & \multirow[b]{3}{*}{ formance Measurer } & $\begin{array}{l}\text { The new remuneration system is able to distinguish } \\
\text { between high-performance employees and those } \\
\text { with low performance (REM5) }\end{array}$ \\
\hline & & $\begin{array}{l}\text { I feel my workload and performance are being } \\
\text { rewarded with this new remuneration(REM6) }\end{array}$ \\
\hline & & $\begin{array}{l}\text { My income from remuneration is in accordance } \\
\text { with the performance and burden of the work that } \\
\text { I do (REM7) }\end{array}$ \\
\hline
\end{tabular}




\section{Discussions}

Tabel 7. Output of Statistic Descriptive Lecturer Respondents

\begin{tabular}{|c|c|c|c|c|c|c|c|}
\hline Dimension & Item & $\mathbf{N}$ & Min & $\operatorname{Max}$ & Mean & Median & Modus \\
\hline \multirow{4}{*}{ Transparency } & REM1 & 53 & 3,000 & 5,000 & 4,321 & 4,000 & 4,000 \\
\hline & REM2 & 53 & 3,000 & 5,000 & 4,340 & 4,000 & 4,000 \\
\hline & REM3 & 53 & 3,000 & 5,000 & 4,302 & 4,000 & 4,000 \\
\hline & REM4 & 53 & 2,000 & 5,000 & 4,321 & 4,000 & 4,000 \\
\hline \multirow{5}{*}{ Justice } & REM5 & 53 & 2,000 & 5,000 & 3,830 & 4,000 & 4,000 \\
\hline & REM6 & 53 & 2,000 & 5,000 & 3,887 & 4,000 & 4,000 \\
\hline & REM7 & 53 & 2,000 & 5,000 & 3,849 & 4,000 & 4,000 \\
\hline & REM8 & 53 & 2,000 & 5,000 & 3,943 & 4,000 & 4,000 \\
\hline & REM9 & 53 & 2,000 & 5,000 & 3,906 & 4,000 & 4,000 \\
\hline \multirow{3}{*}{ Control } & REM10 & 53 & 2,000 & 5,000 & 3,792 & 4,000 & 4,000 \\
\hline & REM11 & 53 & 2,000 & 5,000 & 2,736 & 3,000 & 3,000 \\
\hline & REM12 & 53 & 2,000 & 5,000 & 3,925 & 4,000 & 4,000 \\
\hline \multirow{3}{*}{$\begin{array}{l}\text { Extrinsic } \\
\text { Motivation }\end{array}$} & MOT1 & 53 & 2,000 & 5,000 & 3,849 & 4,000 & 4,000 \\
\hline & MOT2 & 53 & 2,000 & 5,000 & 3,906 & 4,000 & 4,000 \\
\hline & MOT3 & 53 & 2,000 & 5,000 & 3,906 & 4,000 & 4,000 \\
\hline \multirow{4}{*}{$\begin{array}{c}\text { Intrinsic } \\
\text { Motivation }\end{array}$} & MOT4 & 53 & 2,000 & 5,000 & 3,925 & 4,000 & 4,000 \\
\hline & MOT5 & 53 & 2,000 & 5,000 & 3,887 & 4,000 & 4,000 \\
\hline & MOT6 & 53 & 2,000 & 5,000 & 3,943 & 4,000 & 4,000 \\
\hline & MOT7 & 53 & 2,000 & 5,000 & 4,057 & 4,000 & 4,000 \\
\hline Work & KEP1 & 53 & 2,000 & 5,000 & 3,811 & 4,000 & 4,000 \\
\hline Reward & KEP2 & 53 & 2,000 & 5,000 & 3,943 & 4,000 & 4,000 \\
\hline $\begin{array}{c}\text { Career } \\
\text { Opportunity }\end{array}$ & KEP3 & 53 & 2,000 & 5,000 & 3,830 & 4,000 & 4,000 \\
\hline $\begin{array}{c}\text { Work } \\
\text { Condition }\end{array}$ & KEP4 & 53 & 2,000 & 5,000 & 3,660 & 4,000 & 4,000 \\
\hline Work Partner & KEP5 & 53 & 2,000 & 5,000 & 3,943 & 4,000 & 4,000 \\
\hline \multirow{2}{*}{ Quality } & KIN1 & 53 & 2,000 & 5,000 & 3,906 & 4,000 & 4,000 \\
\hline & KIN2 & 53 & 2,000 & 5,000 & 3,830 & 4,000 & 4,000 \\
\hline Quantity & KIN3 & 53 & 1,000 & 5,000 & 3,868 & 4,000 & 4,000 \\
\hline Time & KIN4 & 53 & 1,000 & 5,000 & 3,755 & 4,000 & 4,000 \\
\hline
\end{tabular}

Source : Analyzed Secunder Data, 2018

Table 8. Output of Statistic Descriptive Academic Staff Respondents

\begin{tabular}{|c|c|c|c|c|c|c|c|}
\hline \multirow{2}{*}{ Dimension } & Item & $\mathbf{N}$ & Min & Max & Mean & Median & Modus \\
\hline \multirow{4}{*}{ Transparency } & REM1 & 47 & 4,000 & 5,000 & 4,532 & 5,000 & 5,000 \\
\cline { 2 - 8 } & REM2 & 47 & 1,000 & 5,000 & 4,043 & 4,000 & 5,000 \\
\cline { 2 - 8 } & REM3 & 47 & 1,000 & 5,000 & 3,213 & 3,000 & 2,000 \\
\cline { 2 - 8 } & REM4 & 47 & 1,000 & 5,000 & 2,511 & 2,000 & 2,000 \\
\hline Justice & REM5 & 47 & 2,000 & 5,000 & 3,681 & 4,000 & 4,000 \\
\hline
\end{tabular}




\begin{tabular}{|c|c|c|c|c|c|c|c|}
\hline & REM6 & 47 & 2,000 & 5,000 & 3,745 & 4,000 & 4,000 \\
\hline & REM7 & 47 & 2,000 & 5,000 & 3,702 & 4,000 & 4,000 \\
\hline & REM8 & 47 & 2,000 & 5,000 & 3,809 & 4,000 & 4,000 \\
\hline & REM9 & 47 & 2,000 & 5,000 & 3,681 & 4,000 & 4,000 \\
\hline \multirow{3}{*}{ Control } & REM10 & 47 & 2,000 & 5,000 & 3,638 & 4,000 & 4,000 \\
\hline & REM11 & 47 & 1,000 & 4,000 & 2,596 & 3,000 & 2,000 \\
\hline & REM12 & 47 & 2,000 & 5,000 & 3,766 & 4,000 & 4,000 \\
\hline \multirow{3}{*}{$\begin{array}{l}\text { Extrinsic } \\
\text { Motivation }\end{array}$} & MOT1 & 47 & 2,000 & 5,000 & 3,830 & 4,000 & 4,000 \\
\hline & MOT2 & 47 & 2,000 & 5,000 & 3,872 & 4,000 & 4,000 \\
\hline & MOT3 & 47 & 2,000 & 5,000 & 3,809 & 4,000 & 4,000 \\
\hline \multirow{4}{*}{$\begin{array}{l}\text { Intrinsic } \\
\text { Motivation }\end{array}$} & MOT4 & 47 & 2,000 & 5,000 & 3,830 & 4,000 & 4,000 \\
\hline & MOT5 & 47 & 2,000 & 5,000 & 3,809 & 4,000 & 4,000 \\
\hline & MOT6 & 47 & 2,000 & 5,000 & 3,872 & 4,000 & 4,000 \\
\hline & MOT7 & 47 & 3,000 & 5,000 & 4,043 & 4,000 & 4,000 \\
\hline Work & KEP1 & 47 & 2,000 & 5,000 & 3,787 & 4,000 & 4,000 \\
\hline Reward & KEP2 & 47 & 1,000 & 5,000 & 2,298 & 2,000 & 2,000 \\
\hline $\begin{array}{c}\text { Career } \\
\text { Opportunity }\end{array}$ & KEP3 & 47 & 2,000 & 5,000 & 3,809 & 4,000 & 4,000 \\
\hline Work Condition & KEP4 & 47 & 2,000 & 5,000 & 3,681 & 4,000 & 4,000 \\
\hline Work Partner & KEP5 & 47 & 2,000 & 5,000 & 3,745 & 4,000 & 4,000 \\
\hline \multirow{2}{*}{ Quality } & KIN1 & 47 & 2,000 & 5,000 & 3,787 & 4,000 & 4,000 \\
\hline & KIN2 & 47 & 2,000 & 5,000 & 3,745 & 4,000 & 4,000 \\
\hline Quantity & KIN3 & 47 & 1,000 & 5,000 & 3,681 & 4,000 & 4,000 \\
\hline Time & KIN4 & 47 & 2,000 & 5,000 & 3,745 & 4,000 & 4,000 \\
\hline
\end{tabular}

Source : Analyzed Secunder Data, 2018

Based on table 7 it can be seen that for the number of respondents $(\mathrm{N})$ lecturers as many as 53 people, the mean (median), median and mode of respondent answers are on a Likert scale 4, except for proxy control. This shows that respondents agreed that the current remuneration system can increase motivation, job satisfaction and performance of respondents while working.[12]

While based on table 8 , for the number of respondents $(\mathrm{N})$ academic staff as many as 47 people, the average value (mean), median and mode of respondent's answers are on a Likert scale 4, except for proxy transparency, control and reward. This shows that respondents still do not agree if the remuneration system can increase motivation, job satisfaction and performance of respondents while working.

Tabel 9. Recapitulation of Test Result

\begin{tabular}{|c|c|}
\hline Hypothesis & \multicolumn{1}{c|}{ Description } \\
\hline \hline $1 \mathrm{a}$ & $\begin{array}{l}\text { Remuneration has } \text { significant positive effect on lecturer } \\
\text { motivation }(\mathrm{t}=60,874, \rho<0,05) .\end{array}$ \\
\hline
\end{tabular}




\begin{tabular}{|c|c|}
\hline $1 b$ & $\begin{array}{l}\text { Remuneration has a significant positive effect on academic staff } \\
\text { motivation }(t=49,452, \rho<0,05) \text {. }\end{array}$ \\
\hline $2 \mathrm{a}$ & $\begin{array}{l}\text { Remuneration has a significant positive effect on Lecturer } \\
\text { Performance Satisfaction }(t=81,946, \rho<0,05)\end{array}$ \\
\hline $2 b$ & $\begin{array}{l}\text { Remuneration has a significant positive effect on academic staff } \\
\text { performance satisfaction }(t=53,206, \rho<0,05)\end{array}$ \\
\hline $3 a$ & $\begin{array}{l}\text { Lecturer motivation has a significant positive effect on lecturer } \\
\text { performance }(t=4,444, \rho<0,05)\end{array}$ \\
\hline $3 b$ & $\begin{array}{l}\text { Academic staff has a significant positive effect on academic staff } \\
\text { performance }(t=2,807, \rho<0,05)\end{array}$ \\
\hline $4 a$ & $\begin{array}{l}\text { Job Satisfaction has a significant positive effect on lecturer } \\
\text { performance }(t=2,031, \rho<0,05)\end{array}$ \\
\hline $4 b$ & $\begin{array}{l}\text { Job Satisfaction has a significant positive effect on academic staff } \\
\text { performance }(t=1,067, \rho>0,05)\end{array}$ \\
\hline $5 a$ & $\begin{array}{l}\text { Remuneration has a significant positive effect on lecturer } \\
\text { performance }(t=0,082, \rho>0,05)\end{array}$ \\
\hline $5 b$ & $\begin{array}{l}\text { Remuneration has a significant positive effect on academic staff } \\
\text { performance }(t=1,464, \rho>0,05)\end{array}$ \\
\hline $6 a$ & $\begin{array}{l}\text { Lecturer motivation mediates the relationship between } \\
\text { Remuneration and Lecturer Performance }(t=4,377, \rho<0,05)\end{array}$ \\
\hline $6 b$ & $\begin{array}{l}\text { Academic staff motivation mediates the relationship remuneration } \\
\text { with academic staff performance }(t=2,764, \rho<0,05)\end{array}$ \\
\hline $7 \mathrm{a}$ & $\begin{array}{l}\text { Job Satisfaction mediates the relationship between remuneration } \\
\text { and lecturer performance }(t=2,019, \rho<0,05)\end{array}$ \\
\hline $7 b$ & $\begin{array}{l}\text { Job Satisfaction mediates the relationship remuneration with } \\
\text { academic staff }(t=1,065, \rho>0,05)\end{array}$ \\
\hline
\end{tabular}

Source: ouput SmartPls, analyzed (2018)[13]

\subsection{Effect of Remuneration on Motivation}

Remuneration has a positive effect on employee motivation, both lecturers and education personnel. This shows that remuneration has succeeded in increasing the motivation of UIN Raden Intan Lampung employees.

In accordance with the assumptions of the theory of expectations which states that financial incentives will increase employee motivation and efforts, which in turn will lead to greater productivity. Expectancy theory is based on expectations, values and links. The strength that motivates someone to be active in carrying out his work depends on the reciprocal relationship between what is desired with the needs of the results of the work. According to this theory, motivation is the result of a result to be achieved by a person and the estimate concerned that his actions will lead to the desired results. This means that in this case the author believes that the employees of UIN Raden Intan Lampung see the hope of an outcome to be achieved and the way seems open to obtain it, thereby increasing their motivation to strive to obtain the desired results, in this case compensation finansila in the form of remuneration.[14]

\subsection{Effect of Remuneration on Job Satisfaction}

Remuneration has a positive effect on employee job satisfaction, both lecturers and education personnel. This can be interpreted that remuneration has increased job satisfaction 
of UIN Raden Intan Lampung employees. In accordance with Frederick Herzberg's motivational theory that motivational factors are related to the psychological needs of a person, namely feelings at work and the relationship of respect to the person directly related to work. Job satisfaction is a form of employee work behavior that is defined as a pleasant fit or a positive emotional outcome on one's job assessment.

In the author's opinion, the remuneration system at UIN Raden Intan Lampung has presented a feeling of appreciation for the work done. UIN Raden Intan Lampung employees feel their psychological needs will be met by the remuneration reward, thereby increasing satisfaction with the work done.

\subsection{Effect of Motivation on Performance}

Motivation has a positive influence on performance. From the results of the analysis show that there is a positive influence between motivation variables on employee performance, both lecturers and education staff at UIN Raden Intan Lampung. This means that the higher the motivation of UIN Raden Intan Lampung employees, the higher the performance that will be generated.

In line with the theory of expectations where motivation works depends on the reciprocal relationship between what is desired with the needs of the results of his work. According to Goal Setting Theory, goal setting, challenges and feedback have an influence on performance. Setting these goals informs employees about what and how much effort must be made to achieve the goals. Specific goals can improve performance more than non-specific goals. Goals that are difficult to achieve, if accepted, can produce higher performance than goals that are not too difficult to achieve. Likewise feedback will also lead to better performance than there is no feedback.

\subsection{Effect of Job Satisfaction on Performance}

Job satisfaction has a positive effect on performance. Hypothesis test results indicate that there is a significant positive influence of job satisfaction of lecturers on lecturer performance, but the opposite occurs in educational staff, where the results of hypothesis testing found that there was no significant effect between job satisfaction with performance.[15]

This shows that the level of job satisfaction of UIN Raden Intan Lampung lecturers is higher than the job satisfaction of educational staff. High job satisfaction will motivate employees to improve performance. According to Frederick Herzberg's two-factor theory, a person's motivation is related to job satisfaction, which consists of work performed, success achieved, and opportunities for growth, career advancement and recognition from others.

In the author's opinion, job satisfaction of educational staff at UIN Raden Intan Lampung has no effect on performance due to not achieving the expected benefits by the teaching staff compared to the rewards received by lecturers, thereby reducing motivation to improve performance.

\subsection{Influence of Remuneration on Performance}

Remuneration has a positive effect on performance. From the results of hypothesis testing it was found that the remuneration variable did not have an influence on employee performance, both lecturers and education personnel. This shows that the implementation of the remuneration system at UIN Raden Intan Lampung has not affected employee performance. 
In the author's opinion, the remuneration of the performance at the Raden Intan Lampung UIN has not yet shown that the remuneration system is not yet effective. From the transparency dimension of UIN Raden Intan Lampung employees, both lecturers and education staff still consider the current remuneration system to be unable to provide clear information on what performance requirements or criteria must be met. From the justice dimension of UIN employees, Raden Intan Lampung sees that there is still a discrepancy between the performance burdens of each employee. And from the dimensions of control, lecturers and education staff of UIN Raden Intan Lampung have not been able to plan to what extent they can achieve performance to achieve the desired remuneration.[16]

\subsection{The Effect of Remuneration on Employee Performance through Motivation and Satisfaction Work}

Remuneration has a positive effect on lecturer performance through motivation. This shows that the motivation of lecturers mediates the relationship between remuneration and lecturer performance. In addition remuneration also has a positive effect on lecturer performance through job satisfaction, which means job satisfaction mediates the remuneration relationship and lecturer performance. From this result the writer can say that the better the remuneration system in increasing motivation and job satisfaction will be able to improve employee performance.

While for the tendant respondent obtained results, remuneration affects the performance of the academic staff through motivation. This shows that the tendency motivation mediates the relationship between remuneration and tendency performance. For the mediating effect of job satisfaction the results show that remuneration does not affect the performance of the tendency through job satisfaction. This means that tendency job satisfaction does not mediate the relationship between remuneration and performance. From this result, it can be said that efforts must be made to improve the level of job satisfaction of academic staff employees, in addition to improving the remuneration system that can increase employee motivation and job satisfaction, so as to improve performance.

\section{Conclusion}

Based on the results of tests conducted by researchers, it can be concluded as follows:

The implementation of the remuneration system at UIN Raden Intan Lampung has a positive effect on employee motivation, both lecturers and education personnel. This shows that the application of remuneration at UIN Raden Intan Lampung has provided motivation to employees, both lecturers and students.

The implementation of the remuneration system at UIN Raden Intan Lampung has a positive and significant effect on job satisfaction of employees, both students and lecturers. It also shows that the application of remuneration can increase the level of employee job satisfaction.

Motivation has a significant positive effect on employee performance, both lecturers and students. This means that the higher the level of motivation, the higher the level of performance.[17]

The job satisfaction of lecturers has a significant positive effect on lecturer performance. But tendency job satisfaction does not affect the performance. This shows that the level of job satisfaction of UIN Raden Intan Lampung lecturers is higher than the job satisfaction of educational staff. The job satisfaction of educational staff at UIN Raden Intan Lampung has 
no effect on performance due to the achievement of the expected benefits by the education staff compared to the rewards received by lecturers, thereby reducing motivation to improve performance.

The surprising result is the discovery of evidence that the application of remuneration in Raden Intan Lampung UIN has no influence on the performance of employees, both lecturers and education personnel. The remuneration effect on performance in Raden Intan Lampung UIN shows that the remuneration system is not effective yet. From the transparency dimension of UIN Raden Intan Lampung employees, both lecturers and education staff still consider the current remuneration system to be unable to provide clear information about any performance requirements or criteria that must be met. From the justice dimension of UIN employees, Raden Intan Lampung sees that there is still a mismatch between the performance burdens of each employee. and from the dimensions of control, lecturers and education staff of UIN RadenIntan Lampung have not been able to plan to what extent they can achieve performance to achieve the desired remuneration.

Remuneration has a positive effect on lecturer performance through motivation. This shows that the motivation of lecturers mediates the relationship between remuneration and lecturer performance. In addition remuneration also has a positive effect on lecturer performance through job satisfaction, which means job satisfaction mediates the remuneration relationship and lecturer performance. From this result the writer can say that the better the remuneration system in increasing motivation and job satisfaction will be able to improve employee performance.

While for the tendant respondent the results are obtained, remuneration influences the tendency's performance through motivation. This shows that tendency motivation mediates the relationship between remuneration and tendency performance. For the mediating effect of job satisfaction the results show that remuneration does not affect the performance of the tendency through job satisfaction. This means that tendency job satisfaction does not mediate the relationship between remuneration and performance. From these results it can be said that there must be efforts to improve the level of job satisfaction of tendik employees, in addition to improving the remuneration system that can increase employee motivation and job satisfaction, so as to improve performance.

\section{Reference}

[1] P. Belle, N., \& Cantarelli, "Monetary Incentives, Motivation, and Job Effort in the Public Sector: An Experimental Study With Italian Government Executives," Rev. Public Pers. Adm., vol. 35(2), pp. 99-123, 2015.

[2] dan S. M. B. Bajorek, Zofia M, "Performance-related-pay in the UK public sector," J. Organ. Eff. People Perform., vol. 2(2), pp. 94-109, 2015.

[3] N. Bellé, "Performance-related pay and the crowding out of motivation in the public sector: A randomized field experiment.," Public Adm. Rev., vol. 75(2), pp. 230-241, 2015.

[4] A. H. Braendle, U. C., \& Rahdari, "Corporate Governance and Remuneration,” Theory Pract. Dir. Remun. New Challenges Oppor., 2016.

[5] B. M. Calder, B. J., \& Staw, "Self-Perception of Intrinsic and Extrinsic Motivation," J. Personal. Soc. Psychol., vol. 31(4), pp. 599-605, 1975.

[6] E. N. Chapman, "Managing Part-time Employees a Guide to Better Productivity From Flexible Working," London : Kogan Page., 1994.

[7] K. Bregn, "Detrimental Effects of Performance-Related Pay in the Public Sector? On 
the Need for a Broader Theoretical Perspective," Public Organ. Rev., vol. 13(1), pp. 21-35, 2013.

[8] T. K. Dijkstra, "Latent Variables and Indices: Herman Wold's Basic Design and Partial Least Squares," Handb. Partial Least Squares Concepts, Methods Appl. (Springer Handbooks Comput. Stat. Ser. vol. II), V. Esposito Vinzi, W. W. Chin, J. Henseler H. Wang (eds.), Springer Heidelberg, Dordrecht, London, New York, vol. 23-46, 2010.

[9] P. R. Chin, W. W., Marcolin, B. L., and Newsted, "A Partial Least Squares Latent Variable Modeling Approach for Measuring Interaction Effects: Results from a Monte Carlo Simulation Study and an Electronic-Mail Emotion/Adoption Study," Inf. Syst. Res., vol. 14(2), pp. 189-217, 2003.

[10] A. R. Fitria, R., Idris, A., \& Kusuma, "Pengaruh Remunerasi, Motivasi Dan Kepuasan Kerja Terhadap Kinerja Pegawai Di Kantor Pengadilan Tinggi Agama Samarinda," EJournal Adm. Reform, vol. 2(3), pp. 169-1704., 2014.

[11] S. Burgess, "The Role of Incentives in the Public Sector: Issues and Evidence," Oxford Rev. Econ. Policy, vol. 19(2), pp. 285-300, 2003.

[12] G. A. dan D. I. Churchill, "Marketing Research: Methodological Foundations 10th ed," anada South-Western Cengange Learn., 2010.

[13] M. Hameed, A., Ramzan, M., Hafiz, M., Kashif Zubair, M., Ali, G., \& Arslan, "Impact of compensation on employee performance," Int. J. Bus. Soc. Sci., vol. 5(2), 2014.

[14] B. S. Frey, "Not Just for the Money: an Economic Theory of Personal Motivation," Wiley Online Libr., 1997.

[15] M. Hair, J. F., Hult, G. T. M., Ringle, C. M., and Sarstedt, "A Primer on Partial Least Squares Structural Equation Modeling (PLS-SEM)," 2nd Ed., ThousandOaks Sage, 2017.

[16] M. Frey, B. S., Homberg, F., \& Osterloh, "Organizational Control Systems and Payfor-Performance in the Public Service," Organ. Stud., vol. 34(7), pp. 949-972, 2013.

[17] B. Henseler, J., Fassott, G., Dijkstra, T., and Wilson, "Analysing Quadratic Effects of Formative Constructs by Means of Variance-Based Structural Equation Modelling," Eur. J. Inf. Syst., vol. 21(1), pp. 99-112, 2012. 